\title{
MULTI CRITERIA SUPPLIER SELECTION USING A HYBRID FUZZY AHP- TAGUCHI TECHNIQUE: THE CASE OF TEXTILE INDUSTRY
}

\author{
Wilson Kosasih ${ }^{1}$, Vieren Yulies Triyani, Ahmad, Carla Olyvia Doaly \\ Department of Industrial Engineering Universitas Tarumanagara \\ e-mail: wilsonk@ft.untar.ac.id
}

\begin{abstract}
This paper discusses a method that integrates Fuzzy AHP with Taguchi Loss Function. The method used to select suppliers with various criteria. This various criteria will be considered to get the best supplier. This research was conducted at a textile company in Indonesia for the cotton product 41166. The purpose of this research is to apply techniques to improve the performance of Fuzzy AHP by considering the cost of losses as small as possible. Research data obtained from the survey results using questionnaires and company factual data in the form of costs of losses incurred due to improper quantity of raw materials, quality of raw materials that are not in accordance with standards, delays in delivery, prices that exceed expectations, and poor service or response. The results of this research shown the value of losses incurred by 1 st, 2 nd, 3rd, 4th suppliers respectively for $\$ 2.23, \$ 671.12, \$ 815.57$, and $\$$ 1243.64. Among four suppliers, the best supplier with the smallest loss value is first supplier.
\end{abstract}

Keywords: Supplier Selection, Fuzzy AHP, Taguchi Loss Function

\begin{abstract}
ABSTRAK
Makalah ini membahas metode yang mengintegrasikan Fuzzy AHP dengan Taguchi Loss Function. Metode yang digunakan untuk memilih pemasok dengan berbagai kriteria. Berbagai kriteria ini akan dipertimbangkan untuk mendapatkan pemasok terbaik. Penelitian ini dilakukan pada perusahaan tekstil di Indonesia untuk produk kapas 41166. Tujuan dari penelitian ini adalah menerapkan teknik untuk meningkatkan kinerja Fuzzy AHP dengan mempertimbangkan biaya kerugian sekecil mungkin. Data penelitian diperoleh dari hasil survei dengan menggunakan kuesioner dan data faktual perusahaan berupa biaya kerugian yang timbul akibat kuantitas bahan baku yang tidak tepat, kualitas bahan baku yang tidak sesuai dengan standar, keterlambatan pengiriman, harga yang melebihi ekspektasi, dan layanan atau tanggapan yang buruk. Hasil penelitian ini menunjukkan nilai kerugian yang dialami oleh pemasok ke-1, ke-2, ke-3, ke-4 masing-masing sebesar \$2,23, \$671,12, \$ 815,57, dan \$1243,64. Di antara empat pemasok, pemasok terbaik dengan nilai kerugian terkecil adalah pemasok pertama.
\end{abstract}

Kata kunci: Pemilihan Pemasok, Fuzzy AHP, Taguchi Loss Function

\section{INTRODUCTION}

In the development of manufacturing industry, one aspect that has become a key success factor in industrial competition is the selection of suppliers. The selection of right supplier can reduce cost of material purchases so consequently improve the competitiveness of a company [1]. A supplier selection is very important because the right procurement decision depends on the right supplier [2]. In an effort to know the suppliers itself, a company need to study the supplier's image as well as its track records [3]. Each company has different supplier criteria, depending on the company's objectives. The criteria must reflect the characteristics of raw materials purchased, whereas each characteristic has a different level of importance. MCDM (Multi Criteria Decision Making) techniques such as AHP, ANP, PROMETHEE, Fuzzy AHP, etc are often used in supplier selection. It needs to consider more criteria, thus the selected supplier is a best priority from various aspects of assessment [4].

This research proposes a hybrid method between Fuzzy AHP and Taguchi Loss Function in process of selecting 41166 cotton fabric suppliers. Fuzzy theory is suitable to be applied, because the characteristics of supplier selection problems tend to be fuzzy 


\section{Wilson Kosasih, Vieren Yulies Triyani, Ahmad, Carla Olyvia Doaly}

caused by uncertainty and incomplete information from selection criteria [5],[6]. Fuzzy AHP is applied to determine the ranking of each supplier, which integrated with Taguchi Loss Function technique is used to determine the losses incurred as a consequence of the goods allocation to each supplier based on predetermined selection criteria.

\section{LITERATURE REVIEW}

Analytical Hierarchy Process, often called AHP, was developed in 1980 by Saaty. AHP is a method for selecting the best decision alternatives based on rank when a decision maker has several criteria. AHP relies on the opinion of an expert to obtain a priority scale [7]. It is commonly used in handling qualitative and quantitative criteria on MCDM Method [8]. However, the application of AHP depends on the perception of experts, the model becomes meaningless if the expert gives a wrong assessment. This method is considered to be less able to handle uncertainty in human judgment so that the solution obtained does not answer the purpose of problem [9].

To avoid the risk of errors in interpretation, an appropriate development method can be used to solve the problem called fuzzy AHP [7]. Fuzzy theory functions to accommodate the obscurity of information that occurs in the selection of suppliers with criteria that are not precise [10]. Fuzzy AHP is based on Fuzzy Logic which modifies set theory where each member has a degree of membership that has continuous values between 0 and 1. This set is called a Fuzzy Set. Fuzzy set is based on an idea of extending the range of characteristic functions so that the function will include real numbers at intervals $(0,1)$. The membership value indicates that an item in the universe of conversation is not only at 0 or 1 , but also the value that is in between. While in the crisp set, the membership value is only 2 possibilities, namely 0 or 1 . So, the fuzzy AHP (FAHP) method is a systematic approach in selecting alternatives that involve information in the form of opinions or estimates through the application of both fuzzy set theory concepts and hierarchical structure analysis - AHP [11].

The person who first introduced the concept of fuzzy theory about the obscurity of human thought was Zadeh in 1965 [12]. In 1996, Chang introduced a new approach, using triangular fuzzy numbers for pairwise comparison scales, and used the extent analysis method for synthetic extent from pairwise comparisons [13]. In 1998, Kahraman et.al [11] introduced objective and subjective fuzzy methods using weighting with AHP and fuzzy. In fuzzy AHP, alternatives are sorted by overall weight through the max-min rating application.

Fuzzy theory helps in measuring concepts related to human subjective assessment, using triangular fuzzy linguistics with a triangular fuzzy number (TFN). Triangular fuzzy number is represented by numbers $(1, \mathrm{~m}, \mathrm{u})$ where the strongest membership level is $\mathrm{m}$, with $\mu_{M}(m)=1,1$ is the lower limit and $u$ is the upper limit. Table 1 shows the TFN used for purposes of the pairwise comparison matrix. The membership of triangular fuzzy numbers can be described as seen in Figure 1. The membership function is defined as follows:

$$
\mu_{M}(x)=\left\{\begin{array}{l}
\frac{x-l}{m-l}, l \leq x \leq m \\
\frac{u-x}{u-m}, m \leq x \leq u \quad \text { where }-\infty<1 \leq \mathrm{m} \leq \mathrm{u}<\infty \\
0, \quad \text { Otherwise }
\end{array}\right.
$$


Table 1. Fuzzy Scale and its Linguistic Description [14]

\begin{tabular}{ccc}
\hline $\begin{array}{c}\text { Fuzzy Scale } \\
\text { Intensity }\end{array}$ & $\begin{array}{c}\text { The Opposite of } \\
\text { a Fuzzy Scale }\end{array}$ & Definition of Linguistic Variables \\
\hline $1=(1,1,3)$ & $(1 / 3,1 / 1,1 / 1)$ & Equally important (denoted as "SM") \\
$3=(1,3,5)$ & $(1 / 5,1 / 3,1 / 1)$ & Weak or a little more important (denoted as "SLP") \\
$5=(3,5,7)$ & $(1 / 7,1 / 5,1 / 3)$ & More important (denoted as "LP") \\
$7=(5,7,9)$ & $(1 / 9,1 / 7,1 / 5)$ & Very important (denoted as "SP") \\
$9=(7,9,9)$ & $(1 / 9,1 / 9,1 / 7)$ & Absolute more important (denoted as "MLP") \\
$2=(1,2,4)$ & $(1 / 4,1 / 21 / 1)$ & \\
$4=(2,4,6)$ & $(1 / 6,1 / 41 / 2)$ & Middle value between two ratings \\
$6=(4,6,8)$ & $(1 / 8,1 / 6,1 / 4)$ & \\
$8=(6,8,9)$ & $(1 / 9,1 / 8,1 / 6)$ & \\
\hline
\end{tabular}

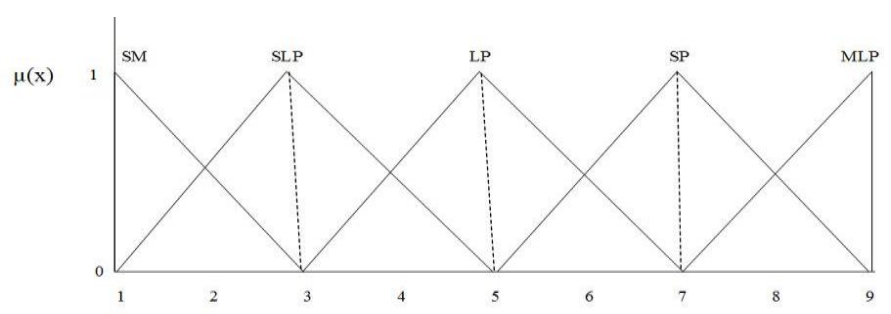

Figure 1. Set of Fuzzy Triangular Numbers [15]

TFN is useful for describing and processing information in a fuzzy scale. The core of fuzzy AHP lies in pairwise comparisons which are described by the ratio scale [16]. TFN expresses "around $\mathrm{x}$ " at intervals of $1 \leq \mathrm{x} \leq 9$ as shown in Table 2 .

\begin{tabular}{cc} 
Table 2. Membership Function of Fuzzy Number [17] \\
\hline Fuzzy Number & Membership Function \\
\hline 1 & $(1,1,3)$ \\
2 & $(1,2,4)$ \\
$\mathrm{x}$ & $(\mathrm{x}-2, \mathrm{x}, \mathrm{x}+2)=(3,5,7)$ \\
8 & $(6,8,9)$ \\
9 & $(7,9,9)$ \\
\hline
\end{tabular}

The application of this method is considered insufficient because it does not take into account the value of losses from each supplier. Taguchi loss function is an effective method for engineering quality, because it takes into account the suitability of goods with predetermined specifications [5]. The purpose of the taguchi loss function is to evaluate the quality loss quantitatively due to variations [18]. Taguchi method was introduced by Dr. Genichi Taguchi [18] in 1949 when he got the task to improve the telecommunications system in Japan. Genichi Taguchi developed a design approach from the perspective of robust design, where products must be designed to be free from defects and high quality. Genichi Taguchi has an idea about quality engineering where the quality design goals are applied to each product and its related processes.

He provides three concepts that aim to improve product quality and process, namely; quality robustness, quality loss function, and target oriented quality. In this study more emphasis and discussion about Taguchi Loss Function (TLF). This technique identifies all costs related to low quality and shows how these costs increase if the quality of the product is further away from the customer's desires. These costs not only include customer dissatisfaction, but also warranty and service costs, internal inspection fees, repairs, scrap, and other costs that are considered as costs to the community. Quality loss function is used to find out how much the expected losses are borne by the company. Expected losses are 
obtained when the output of products produced in the production process does not meet the set targets [19].

\section{METHOD}

This research was conducted in a textile company by taking primary and secondary data. The first step is to determine the criteria that influence supplier selection by conducting interviews with several purchasing and marketing department staff. Then based on these criteria a hierarchical structure was created and data collection was carried out using a questionnaire distributed to employees who have worked in the company for more than 3 years. This questionnaire was used to determine the weight of each criterion in supplier selection and compare each supplier alternative in meeting each given criteria.

Based on the results of questionnaire, paired comparison was carried out for each respondent. Then do fuzzification to change the value of crisp to triangular fuzzy number. Fuzzification is done to minimize the subjectivity in the questionnaire assessment. After obtaining a fuzzy value, the value is changed back to the new crisp value so that it can be normalized to get the eigen vector value. The next step is to calculate the consistency ratio (CR) to find out whether the questionnaire is consistent and can be used, if the questionnaire data from each respondent is consistent then the Geometric Mean can be calculated using the equation below.

$$
\text { Geomean }=\sqrt[n]{S 1 \times S 2 \times S 3 \times \ldots \times S n}
$$

The next step is to compare fuzzy synthetic extent values for each sub-criteria and alternative suppliers, then maximize and minimize operations to get the weight values of each supplier's criteria and alternatives. This weight will be integrated into the Taguchi Loss Function Technique.

$$
V\left(M_{2} \geq M_{1}\right)= \begin{cases}1, & \text { if } m_{2} \geq m_{1} \\ 0, & \text { else if } l_{1} \geq u_{2} \\ \frac{l_{1}-u_{2}}{\left(m_{2}-u_{2}\right)-\left(m_{1}-l_{1}\right)} & \text { otherwise }\end{cases}
$$

The next stage is to identify the costs that arise related to each criterion for each supplier. Before calculating the target value, it is necessary to calculate the constant value first. Here is the formula to find the value of constant losses.

$$
L(x)=k \times(x-t)^{2}
$$

Where, $L(x)$ is loss in currency units, $k$ is a loss constant, $x$ is the highest value of product sales, $t$ is the normal value of product sales.

Next we identify the type of quality loss function of each criterion where there are 3 types of target that need to be achieved. The first type is nominal the best has the understanding that it is better to be within the tolerance limit or a predetermined target. Criteria such as quantity and delivery are included in this target type, nominal the best. Where the Taguchi equation for calculating the losses caused by the product can be stated as follows:

For 1 unit product

$$
L(y)=k(y-m)^{2}
$$

For more than 1 unit product

$$
L(y)=k\left[\sigma^{2}+(y-m)^{2}\right]
$$


The second type, smaller the better has the understanding that it is better to choose the least value. Criteria such as price, quality, and service are included in this type, smaller the better. Where the Taguchi equation for calculating the losses caused by the product can be stated as follows:

For 1 unit product

$$
L(y)=k \times y^{2}
$$

For more than 1 unit product

$$
L(y)=k\left(\sigma^{2}+y^{2}\right)
$$

Where, $y$ is the quality characteristic of finished product, $L(y)$ is the loss of a currency unit when the product characteristics are equal to " $y$ ", $\mathrm{m}$ is quality characteristic that is the real " $y$ " target, $k$ is a loss constant, $\sigma$ is standard deviation, $y^{2}$ is a tolerance value determined by the company.

The third type, largest the best states that the greater the target value achieved, the better the quality of a product. Where the Taguchi equation for calculating the losses caused by the product can be stated as follows:

For 1 unit product

$$
\begin{aligned}
& L(y)=k \frac{1}{y^{2}} \\
& k=A_{0} \cdot \Delta^{2}
\end{aligned}
$$

For more than 1 unit product

$$
\begin{aligned}
& L(y)=k(M S D) \\
& L(y)=\frac{k}{\mu^{2}}\left[1+\frac{3 \sigma^{2}}{\mu^{2}}\right]
\end{aligned}
$$

The last step is to multiply the calculation results from the loss function with the weight of each criterion from the previous results. The total losses for each criterion will be multiplied by the weight of each criterion. The results of this calculation will determine the value of losses arising from each supplier.

\section{RESULTS AND DISCUSSION Fuzzy AHP}

Table 3 shows the viewpoint of each supplier selection criterion for this study. These perspectives are grouped into 10 criteria which can be seen in table below.

Table 3. Selection Criteria and its Viewpoint

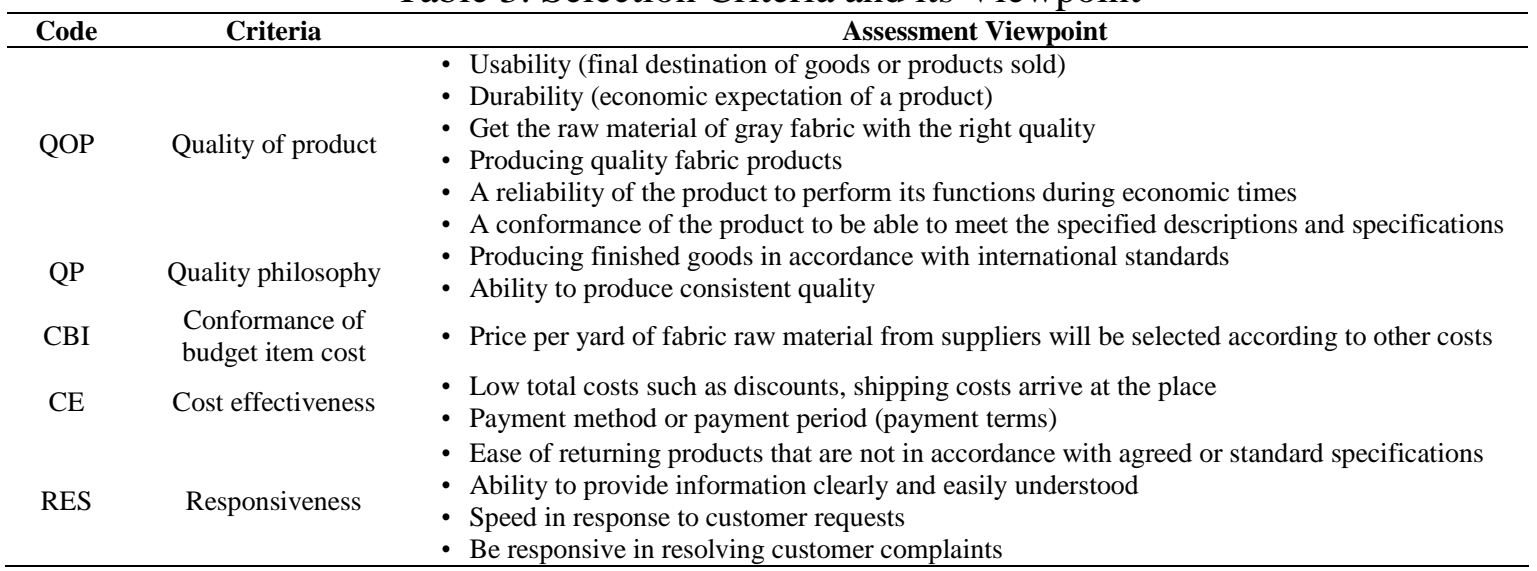


Continued Table 3. Selection Criteria and its Viewpoint

\begin{tabular}{|c|c|c|}
\hline Code & Criteria & Assessment Viewpoint \\
\hline WAC & $\begin{array}{l}\text { Warranties and claim } \\
\text { policies }\end{array}$ & $\begin{array}{l}\text { - Provide guarantees for goods } \\
\text { - Provide assistance in an emergency } \\
\text { - Provide compensation policies } \\
\text { - Ability }\end{array}$ \\
\hline PHP & $\begin{array}{l}\text { Performance history } \\
\text { and reputation }\end{array}$ & $\begin{array}{l}\text { - Ability to fulfill the number of orders } \\
\text { - Ability to maintain contractual agreements } \\
\text { - Ability to fulfill quantity against a predetermined schedule } \\
\text { - Good name and business experience (length of business in a certain field) } \\
\text { - Good management and organization conditions }\end{array}$ \\
\hline MO & $\begin{array}{l}\text { Management and } \\
\text { organization }\end{array}$ & $\begin{array}{l}\text { - Completeness of company documents } \\
\text { - Completeness of the goods offer documents } \\
\text { - Certification }\end{array}$ \\
\hline COD & $\begin{array}{l}\text { Conformance of } \\
\text { delivery }\end{array}$ & $\begin{array}{l}\text { - Timeliness of fabric delivery } \\
\text { - The accuracy of quantity delivered } \\
\text { - Quality of goods received } \\
\text { - Lead time }\end{array}$ \\
\hline FLE & Flexibility & $\begin{array}{l}\text { - Ease in adding or reducing raw material purchases } \\
\text { - Ease of changing delivery schedules }\end{array}$ \\
\hline
\end{tabular}

The object of research was suppliers of 41166 raw material. There were 4 alternative suppliers to be selected. Elements of the hierarchical structure determined consist of 3 levels, namely objectives, main criteria, and alternative suppliers, as illustrated in Figure 2.

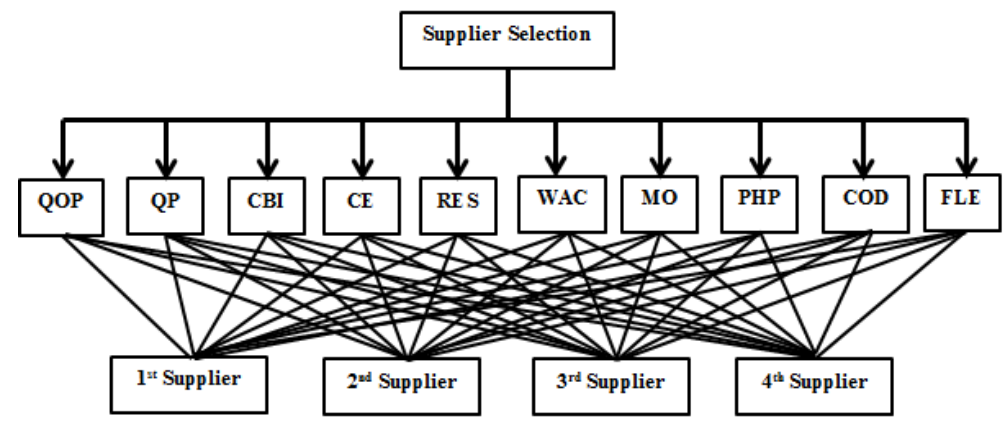

Figure 2. A hierarchical structure of decision

First of all, the weight value of AHP is converted to Triangular Fuzzy Number. Furthermore, the consistency of these results was tested. Then the lower, middle, and upper values are combined to calculate Fuzzy synthetic extent values for each criterion. The fuzzy synthetic comparison results indicate the weight or ranking of each alternative supplier, as shown in Table 4.

Table 4. Results of Fuzzy Synthetic Comparison

\begin{tabular}{lccccccccccc}
\hline \multirow{2}{*}{ Alternative } & QOP & QP & CBI & CE & RES & WAC & PHP & MO & FLE & COD & \multirow{2}{*}{ weight } \\
\cline { 2 - 10 } & $\mathbf{0 . 1 3 1 1}$ & $\mathbf{0 . 0 7 7 8}$ & $\mathbf{0 . 1 0 4 0}$ & $\mathbf{0 . 0 9 2 2}$ & $\mathbf{0 . 1 0 7 0}$ & $\mathbf{0 . 0 9 9 7}$ & $\mathbf{0 . 0 8 7 7}$ & $\mathbf{0 . 0 6 6 2}$ & $\mathbf{0 . 1 1 6 8}$ & $\mathbf{0 . 1 1 7 3}$ & \\
\hline Supplier \#1 & 0.5854 & 0.8729 & 0.0984 & 0.3140 & 0.2948 & 0.3155 & 0.3046 & 0.2764 & 0.2597 & 0.4427 & 0.3742 \\
Supplier \#2 & 0.2275 & 0.1271 & 0.3864 & 0.2643 & 0.2771 & 0.2970 & 0.3046 & 0.2605 & 0.2567 & 0.2829 & 0.2707 \\
Supplier \#3 & 0.1871 & 0.0000 & 0.2953 & 0.1508 & 0.2279 & 0.2881 & 0.2225 & 0.2762 & 0.2238 & 0.1559 & 0.2045 \\
Supplier \#4 & 0.0000 & 0.0000 & 0.2199 & 0.2708 & 0.2000 & 0.0995 & 0.1682 & 0.1868 & 0.2597 & 0.1185 & 0.1505 \\
\hline
\end{tabular}

To further simplify the integration phase with Taguchi Loss Function, not all of the criteria analyzed further have impact their costs. Based on discussions with company management, it was agreed that the criterion, which has a weight of below 0.10 , could be ignored. Therefore, there are only 5 criteria are discussed in more detail using the Taguchi method approach, as shown in Table 5. The top ranking for alternative suppliers based on Fuzzy AHP method is 1-2-3-4. This weight would be integrated into the calculation of Taguchi Loss Function. 
Table 5. Final Result of Fuzzy AHP

\begin{tabular}{lcccccc}
\hline \multirow{2}{*}{ Alternative } & QOP & CBI & RES & FLE & COD & \multirow{2}{*}{ Weight } \\
\cline { 2 - 6 } & $\mathbf{0 . 2 1 6 9}$ & $\mathbf{0 . 1 8 2 1}$ & $\mathbf{0 . 1 8 7 6}$ & $\mathbf{0 . 2 1 0 2}$ & $\mathbf{0 . 2 0 3 1}$ & \\
\hline Supplier \#1 & 0.5854 & 0.0984 & 0.2948 & 0.2597 & 0.4426 & 0.3447 \\
Supplier \#2 & 0.2275 & 0.3864 & 0.2771 & 0.2567 & 0.2828 & 0.2831 \\
Supplier \#3 & 0.1870 & 0.2952 & 0.2279 & 0.2238 & 0.1559 & 0.2158 \\
Supplier \#4 & 0.0000 & 0.2199 & 0.2000 & 0.2597 & 0.1185 & 0.1562 \\
\hline
\end{tabular}

\section{Taguchi Loss Function}

As mentioned before, there are 5 criteria in supplier selection which will be discussed in more detail using the Taguchi method approach, namely quality of product, conformance of item budget, responsiveness, conformance of delivery, and flexibility. Based on historical data from August 2016 to September 2017 from purchasing department, the following data is obtained. Table 6 indicates the performance of each supplier in terms of the quantity of goods delivered, Table 7 shows the performance of each supplier in terms of the timeliness of delivery, Table 8 indicates the performance of each supplier in terms of whether the goods are delivered in defects, Table 9 indicates the performance of each supplier reviewed from the price of goods, while Table 10 indicates the performance of each supplier in terms of the speed of supplier response.

Table 6. Quantity of Goods

\begin{tabular}{ccccc}
\hline \multirow{2}{*}{ Month } & \multicolumn{4}{c}{ Alternative Supplier } \\
\cline { 2 - 5 } & $\mathbf{\# 1}$ & $\mathbf{\# 2}$ & $\mathbf{\# 3}$ & $\mathbf{\# 4}$ \\
\hline Aug-2016 & 0 & + & 0 & 0 \\
Sep-2016 & 0 & 0 & 0 & + \\
Feb-2017 & 0 & 0 & 0 & + \\
Jun-2017 & + & 0 & 0 & 0 \\
Sep-2017 & 0 & 0 & + & - \\
\hline
\end{tabular}

The quantity of goods received according to order is given a value of 0 . If there is excess, it is given a positive sign, otherwise if it is less than the order it is given a negative sign.

Table 7. Delivery Performance

\begin{tabular}{ccccc}
\hline \multirow{2}{*}{ Month } & \multicolumn{4}{c}{ Alternative Supplier } \\
\cline { 2 - 5 } & $\mathbf{\# 1}$ & $\mathbf{\# 2}$ & $\mathbf{\# 3}$ & $\mathbf{\# 4}$ \\
\hline Aug-2016 & 0 & + & - & 0 \\
Sep-2016 & 0 & 0 & 0 & - \\
Feb-2017 & 0 & 0 & 0 & 0 \\
Jun-2017 & 0 & 0 & 0 & 0 \\
Sep-2017 & + & 0 & - & 0 \\
\hline
\end{tabular}

Supplier delivers goods on time given a value of 0 . If the goods are delivered faster than the time set then given a positive sign, on contrary if the goods are delivered late or longer than the time set then given a negative sign.

Table 8. Defect of Goods

\begin{tabular}{ccccc}
\hline \multirow{2}{*}{ Month } & \multicolumn{4}{c}{ Alternative Supplier } \\
\cline { 2 - 5 } & $\mathbf{\# 1}$ & $\mathbf{\# 2}$ & $\mathbf{\# 3}$ & $\mathbf{\# 4}$ \\
\hline Aug-2016 & 0 & 0 & - & 0 \\
Sep-2016 & 0 & 0 & 0 & - \\
Feb-2017 & 0 & 0 & 0 & 0 \\
Jun-2017 & 0 & 0 & 0 & - \\
Sep-2017 & 0 & 0 & 0 & 0 \\
\hline
\end{tabular}




\section{Wilson Kosasih, Vieren Yulies Triyani, Ahmad, Carla Olyvia Doaly}

If the supplier delivers goods that are not in accordance with the requested quality, as well as the item received is defective, then it is given a negative sign. If it is appropriate, then it is given a value of 0 .

Table 9. Price

\begin{tabular}{ccccc}
\hline \multirow{2}{*}{ Month } & \multicolumn{4}{c}{ Alternative Supplier } \\
\cline { 2 - 5 } & $\mathbf{\# 1}$ & $\mathbf{\# 2}$ & $\mathbf{\# 3}$ & $\mathbf{\# 4}$ \\
\hline Aug-2016 & 0 & 0 & 0 & 0 \\
Sep-2016 & 0 & 0 & 0 & 0 \\
Feb-2017 & 0 & 0 & 0 & 0 \\
Jun-2017 & 0 & 0 & 0 & 0 \\
Sep-2017 & 0 & 0 & 0 & 0 \\
\hline
\end{tabular}

If the price offered by the supplier in accordance with the maximum limits and still be within tolerable limits, or in other words, does not result in the company suffered a loss, it can be given a value of 0 . On contrary, if the price is above the tolerance limit, it can be given a negative sign.

Table 10. Supplier's Response

\begin{tabular}{ccccc}
\hline \multirow{2}{*}{ Month } & \multicolumn{4}{c}{ Alternative Supplier } \\
\cline { 2 - 5 } & $\mathbf{\# 1}$ & $\mathbf{\# 2}$ & $\mathbf{\# 3}$ & $\mathbf{\# 4}$ \\
\hline Aug-2016 & 0 & 0 & 0 & 0 \\
Sep-2016 & 0 & 0 & - & 0 \\
Feb-2017 & 0 & - & 0 & 0 \\
Jun-2017 & 0 & 0 & 0 & 0 \\
Sep-2017 & 0 & 0 & - & - \\
\hline
\end{tabular}

If the supplier's response is fast or in line with expectations, it is given a value of 0 . Whereas, if the supplier's response is slow or not as expected, then a negative sign is given.

Both positive and negative signs cause losses for the company. An example is the delivery performance, given a positive sign if the supplier sends raw materials faster than the schedule should, given a negative sign if the supplier delivers raw materials later than the schedule they should. Late delivery results in a delayed production process or a shorter lead time to reach the customer's hands. Meanwhile, faster delivery results in other additional costs due to production machinery that is not yet available so that raw materials will wait to be processed.

The losses incurred by the company, for errors or violations from each supplier, are different. The average loss per event obtained from the first supplier is $\$ 0.50$, the second supplier is $\$ 0.47$, the third supplier is $\$ 0.56$, and the fourth supplier is $\$ 0.31$. Table 11 shows the results of the loss function values for each criterion.

Table 11. Results of Loss Function Value

\begin{tabular}{ccc}
\hline Supplier & Losses Nominal the Best Value & Losses Smaller the Better Value \\
\hline Supplier \#1 & $\$ 3.24$ & $\$ 942.24$ \\
Supplier \#2 & $\$ 0.47$ & $\$ 2,369.27$ \\
Supplier \#3 & $\$ 4.50$ & $\$ 1,254.65$ \\
Supplier \#4 & $\$ 0.38$ & $\$ 2,652.44$ \\
\hline
\end{tabular}

Table 12 shows the summary of losses of each supplier for each criterion. Furthermore, this result is multiplied by the weight of Fuzzy AHP results for the five criteria to obtain the losses of each supplier, as shown in Table 13. 
Table 12. Losses of Each Supplier for Each Criterion

\begin{tabular}{|c|c|c|c|c|c|c|c|c|}
\hline \multirow{3}{*}{$\begin{array}{l}\text { Criteria } \\
\text { Quantity }\end{array}$} & \multicolumn{8}{|c|}{ Alternative } \\
\hline & \multicolumn{2}{|c|}{ Supplier \#1 } & \multicolumn{2}{|c|}{ Supplier \#2 } & \multicolumn{2}{|c|}{ Supplier \#3 } & \multicolumn{2}{|c|}{ Supplier \#4 } \\
\hline & $\$$ & 3.24 & $\$$ & 0.47 & $\$$ & 4.50 & $\$$ & 1.13 \\
\hline Delivery & $\$$ & 3.24 & $\$$ & 0.47 & $\$$ & 8.99 & $\$$ & 0.38 \\
\hline Service & $\$$ & - & & 69.27 & & 09.30 & & 2.44 \\
\hline Quality & $\$$ & - & $\$$ & - & & 54.65 & & 4.87 \\
\hline Price & $\$$ & - & $\$$ & - & $\$$ & - & $\$$ & - \\
\hline
\end{tabular}

The smallest loss is caused by the first supplier with a loss of $\$ 2.23$. The next consecutive is the second supplier with a loss value of $\$ 671.12$, the third supplier with a loss value of $\$ 815.37$, and finally the fourth supplier with the largest loss value of $\$$ 1243.64, as shown in Table 13. Meanwhile, so far the selection of suppliers is based more on the opinions of the managers and directors of this company where the order of suppliers from the best is the first, second, fourth, and third supplier. But if it is assessed from the losses incurred, the order of suppliers starts with the smallest loss is the first, second, third, and fourth supplier.

Table 13. Losses, Weight and Ranking of Each Supplier

\begin{tabular}{|c|c|c|c|c|c|c|c|c|c|c|}
\hline Alternative & Quantity & Delivery & Service & Quality & \multicolumn{2}{|c|}{ Price } & \multicolumn{2}{|r|}{ Total } & \multirow{2}{*}{$\begin{array}{c}\text { Weight } \\
0.00082\end{array}$} & \multirow{2}{*}{$\frac{\text { Rank }}{1}$} \\
\hline Supplier \#1 & $\$ 1.12$ & $\$ 1.12$ & $\$-$ & $\$-$ & $\$$ & - & $\$$ & 2.23 & & \\
\hline Supplier \#2 & $\$ 0.13$ & $\$ 0.13$ & $\$ 670.86$ & $\$$ & $\$$ & - & $\$$ & 671.12 & 0.24562 & 2 \\
\hline Supplier \#3 & $\$ 0.97$ & $\$ 1.94$ & $\$ 541.64$ & $\$ 270.82$ & $\$$ & - & $\$$ & 815.37 & 0.29841 & 3 \\
\hline Supplier \#4 & $\$ 0.18$ & $\$ 0.06$ & $\$ 414.47$ & \$ 828.94 & $\$$ & - & & ,243.64 & 0.45515 & 4 \\
\hline & &, 732.37 & 1.00000 & \\
\hline
\end{tabular}

The results of the integration of AHP-TLF and Fuzzy AHP-TLF show a nonsignificant difference in total losses, so that this study does not change the ranking of each supplier. This is because the weighting results between the AHP and Fuzzy-AHP methods are not significantly different. However, the integration of the Taguchi Loss Function is considered effective and can reduce subjective bias in supplier selection or other decision making.

Table 14. Results of Ranking for Each Method

\begin{tabular}{|c|c|c|c|c|c|c|c|c|c|c|}
\hline \multirow[b]{2}{*}{ Goal } & \multicolumn{2}{|c|}{ AHP } & \multicolumn{2}{|c|}{ Fuzzy AHP } & \multicolumn{3}{|c|}{ AHP-TLF } & \multicolumn{3}{|c|}{ FAHP-TLF } \\
\hline & Weight & Rank & Weight & Rank & $\begin{array}{c}\text { Total } \\
\text { Losses }\end{array}$ & Weight & Rank & $\begin{array}{c}\text { Total } \\
\text { Losses }\end{array}$ & Weight & Rank \\
\hline Supplier \#1 & 0.370 & 1 & 0.374 & 1 & $\$ 2.34$ & 9E-04 & 1 & $\$ 2.23$ & $8 \mathrm{E}-04$ & 1 \\
\hline Supplier \#2 & 0.260 & 2 & 0.271 & 2 & $\$ 641.45$ & 0.234 & 2 & $\$ 671.12$ & 0.245 & 2 \\
\hline Supplier \#3 & 0.200 & 3 & 0.205 & 3 & $\$ 755.69$ & 0.276 & 3 & $\$ 815.37$ & 0.298 & 3 \\
\hline Supplier \#4 & 0.160 & 4 & 0.151 & 4 & $\$ 1.338 .63$ & 0.489 & 4 & $\$ 1,243.64$ & 0.455 & 4 \\
\hline
\end{tabular}

\section{CONCLUSION}

This study successfully integrates Fuzzy AHP with Taguchi Loss Function in supplier selection by considering the criteria ie quantity, delivery, service, quality, and price. Based on the overall results, it can be concluded that using fuzzy AHP with Taguchi Loss Function integration where the selected supplier for 41166 cotton fabric with the smallest loss value is the first supplier.

The suggestion from this research is that this company should not choose the fourth supplier, because the supplier raises the highest loss value. This company should make improvements in determining the quantity of ordering raw materials, so that orders for the fourth supplier can begin to be reduced and can even be transferred to other suppliers. To support the accuracy of the data, the company should record more detailed and real time so that the loss value can be calculated more optimally and more precisely. 
Multi Criteria Supplier Selection Using a Hybrid Fuzzy AHP-Taguchi Technique (Case Study: A Textile

Company)

Wilson Kosasih, Vieren Yulies Triyani, Ahmad, Carla Olyvia Doaly

\section{REFERENCES}

[1]. Xia, Weijun \& Zhiming, W. 2007. Supplier Selection with Multiple Criteria in Volume Discount Environments. Int J Mgmt Sci., 35(5), pp. 494-504.

[2]. Bayazit, O., Birsen, K. \& Ayhan, Y.A. 2006. Purchasing Decision: Selecting a Supplier for a Construction Company. Journal System Science System Engineering (Springer-Verlag), 15(2), pp. 217-231.

[3]. Saaty, T.L. \& Vargas, L.G. 2012. Models, Methods, Concepts \& Applications of the Analytical Hierarchy Process. New York, US: Springer Science \& Business Media, pp. 1-39.

[4]. Indrapriyatna, Ahmad S, Meuthia, Y., Fatrias, D. \& Gusti, M. 2011. Integrasi Taguchi Loss Function dengan Fuzzy Analytical Hierarchy Process dalam Pemilihan Pemasok. Jurnal Teknik Industri, 13(2), pp. 66-72.

[5]. Amid, A., Ghodsypour, S. H. \& O’Brien, C. 2006. Fuzzy Multiobjective Linear Model for Supplier Selection in A Supply Chain. International Journal Production Economics, 104, pp. 394-407.

[6]. Kosasih, W. 2016. Fuzzy Assessment Simulation for Classifying Production Equipment in Practice of Total Productive Maintenance. ARPN Journal of Engineering and Applied Sciences, 11(8), pp. 5261-5268.

[7]. Ozdagoglu, A. \& Ozdagoglue, G. 2007. Comparisons of AHP and Fuzzy AHP for the Multi-Crtieria Decision Making Processes with Linguistic Evaluations. Istanbul Ticret University Fen Bilimleri Dergisi, 6(11), pp. 65-85.

[8]. Chang, D. Y. 1996. Applications of The Extent Analysis Method on Fuzzy AHP. European Jurnal of Operational Research, 95, pp 649-655.

[9]. Saaty, T. L. 1993. Pengambilan Keputusan Bagi Para Pemimpin, Proses Hirarki Analitik untuk Pengambilan Keputusan dalam Situasi yang Kompleks. ID: Pustaka Binama Pressindo.

[10].Zimmermann, H. J. 1978. Fuzzy Programming and Linear Programming with Several Objective Functions. Journal of Fuzzy Sets and Systems, 1, pp. 45-55.

[11]. Kahraman, Cengiz, Cebeci, Ufuk \& Ulukan, Ziya. 2004. Multi-attribute Comparison of Catering Service Companies Using Fuzzy AHP: The Case of Turkey. International Journal of Production Economics, 87(2), pp.171-184.

[12]. Lam, Ka-Chi, Lam, Mike Chun-Kit \& Wang, D. 2008. MBNQA-Oriented Self Assessment Quality Management System for Contractors: Fuzzy AHP Approach. Journal construction management and economics, 26, pp. 447-461.

[13]. Chang, Da-Yong. 1996. Applications of the Extent Analysis Method on Fuzzy AHP. European Journal of Operation Research, 95, p. 649.

[14]. Chuang, M.L. \& Liou, J.H. 2008. A Hybrid MCDM model for evaluating the corporate image of the airline industry. International Journal of Applied Management Science, 1, pp. 41-54.

[15]. Chiou, Hua-Kai, Wan, Chia-Chin \& Tzeng, Gwo-Hshiung. 2005. Fuzzy AHP with MCDA to construct te Roadmap of R\&D Consortia in Taiwan's M\&S Enterprises. Paper presented at ISAHP 2005, Honolulu-Hawaii (pp. 1-11).

[16]. Terano, T., Asai, K. \& Sugeno, M. 1992. Fuzzy System Theory and It's Applications. London, UK: Academic Press, Inc., p. 8.

[17]. Deng, Hepu. 1999. Multi-criteria Analysis with Fuzzy Pairwise Comparison. International Journal of Approximate Reasoning, 21, pp. 215-231.

[18]. Belavendram, Nicolo. 1995. Quality by Design: Taguchi Techniques for Industrial Expermentation. New York, US: Prentice Hall. 
[19]. Ginting, E.S., Pujangkoro, S. \& Sinaga, T.S. 2014. Evaluasi Supplier Bahan Baku Pembuatan Tiang Pancang pada PT. XYZ dengan Menggunakan AHP dan Loss Function. e-Jurnal Teknik Industri FT USU, 3(1), pp. 1-5. 